\title{
Estimation Carbon Storage of Community Forest through Timber Legality Assurance System
}

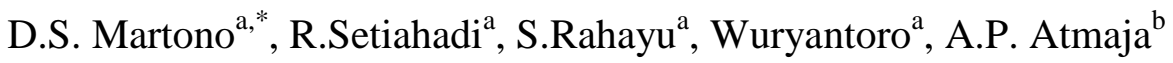 \\ ${ }^{a}$ Faculty of Agriculture, University of Merdeka Madiun, Serayu 79 ${ }^{\text {th }}$, Madiun,63133, Indonesia \\ E-mail: *djokosetyo@unmer-madiun.ac.id \\ ${ }^{b}$ Politeknik Negeri Madiun, Serayu $84^{\text {th }}$, Madiun, 63133, Indonesia
}

\begin{abstract}
Community forests play an important role in reducing greenhouse gas emissions because forests can absorb carbon dioxide in the air, which then stored in trees. The measurement of the amount of $\mathrm{C}$ stored in plant life in a community forest can illustrate the amount of $\mathrm{CO}$ in the atmosphere absorbed by plants. The research activity aims to estimate carbon stocks in community forests certified by TLAS (Timber Legality Verification System). The method used is the making of allometric equations by logging methods of commercial tree species (Melia, Mahagony, Tectona grandis, and Paraserianthes). The location of the research conducted in the community forest area managed by Lawu Lestari People's Law Enforcement Community (PPHR), Panekan, Magetan. With an area of 192.16 hectares scattered in three (3) villages, namely Ngiliran, Jabung, and Bedagung, and obtained certified SVLK on December 4, 2013. The average percentage of biomass per part of the main tree for community forest the largest is Stem 50.28\%, $\mathbf{2 8 . 0 0 \%}$ Branches and twigs, root $\mathbf{1 4 . 2 6 \%}$, leaves $\mathbf{7 . 4 6 \%}$. Equation model to estimate the amount of carbon content Melia azedarach $\mathrm{Y}$ $=246,123 \mathrm{~d}^{1,986}(\mathrm{R} 2=0,999$ and $\mathrm{SEE}=0,053)$, Swietenia mahagony $\mathrm{Y}=48,389 \mathrm{~d}^{2,443}(\mathrm{R2}=0,997, \mathrm{SEE}=0,083)$, Tectona grandis $\mathrm{Y}=$ $65,019 \mathrm{~d}^{2,370}(\mathrm{R} 2=0.995$ and $\mathrm{SEE}=0.122)$ and Paraserianthes falcataria $\mathrm{Y}=52.726 \mathrm{~d}^{2.116}(\mathrm{R} 2=0.993, \mathrm{SEE}=0.123)$. The amount of carbon content amounted to community forest is $\mathbf{2 5 5 8 . 6 9}$ tons.
\end{abstract}

Keywords — carbon stock; community forest; TLAS; wood legality.

\section{INTRODUCTION}

The ability of forests to absorb and store Carbon is not the same in natural forests, plantations, brackish forests, swamp forests, and people's forests and dependent on tree species, soil types, and topography. At present, comprehensive data sources on carbon stocks in different kinds of forest ecosystems and other land uses are limited [1]. People's forest is a forest that grows on community land, both in the yard (around the dwelling house), a moor (dry soil commonly planted with crops other than rice), as well as rice fields [2]. Wood from the forest is widely using to build construction, furniture, handicrafts that ultimately can improve the level of the farming economy [3].

In addition to the above functions, people forest also has an ecological service that is instrumental in maintaining the balance of ecosystems. One of them is forest function in preserving climate and related to the ability of the forest stand to absorb carbon dioxide and release oxygen in the process of photosynthesis. The carbon dioxide absorbed by plants and stored in carbon biomass can reduce the risk of adverse greenhouse effects [4], [5]. Through the process of plant photosynthesis, the rate of increase in carbon dioxide emissions will be balancing. Carbon is a significant component of the biomass of plants through the process of photosynthesis. The increase in carbon dioxide in the atmosphere globally has caused environmental problems [4].

The measurement of the amount of $\mathrm{C}$ stored in the body of a living plant (biomass) in a community forest can illustrate the amount of $\mathrm{CO}$ in the atmosphere absorbed by the plant [6]. The measurement of reserves that still stored in parts of plants that have died (necromass) indirectly describes the $\mathrm{CO}$ that is not releasing into the air through combustion [7]. Degradation of land and forests in Indonesia that are not accompanied by long-term land protection will affect soil and environmental quality [8]. Deforestation triggered by forest management by governments, policies that are not favored by indigenous peoples and forests. Deforestation activities come in many ways, including forest fires, logging, and mining. The causes of this deforestation are relatively different effects on nature [9].

The Government of Indonesia in 2009 established the obligation to comply with the Timber Legality Assurance System (TLAS) standard on timber products for timber business to ensure the full legality of wood products. The 
provision intended to eliminate any doubt on the validity of Indonesian timber traded on the international market [10]. TLAS is a system that guarantees timber forest and timber legality sustainability and timber tracking through certification of Sustainable Production Forest Management (PHPL), Certification of Timber Legality (S-LK), and Supplier Conformity Declaration (DKP) [11], [12].

One of the essential roles of community forests that are still rarely known by many people, especially for the managers themselves, is its ability to store Carbon. The purpose of community forest in storing Carbon is beneficial if integrated with the strength of managers in preserving the forest [13]. The planting of community forests will create a double benefit; that is, the land becomes more productive because it is rehabilitating, generating economic income, and carbon sinks that can help combat the effects of climate change [14]. This study aims to measure carbon stocks from community forest certified S-LK by destructive (destructive method) with the help of making allometric formula from the main tree of the community forest, especially in the research area.

\section{MATERIAL AND METHOD}

\section{A. Material}

Material from this study is the land belongs to the people who are members of PPHR Lawu Lestari in the Ngiliran sub-district, Bedagung and Jabung District of Panekan Magetan, East Java, Indonesia. The study conducted for 2 (two) years. The tools used in this study are: Chainsaw, Hoe, Pecok, Machete, Scales hanging, Ohaus Scales, Ribbon meter, Plastic strap, Open, Paper Packaging, Camera, GPS, and Stationery.

\section{B. Methods}

The making of allometric equations is doing by the destructive method of logging on selected sample trees from 3 (three) villages, which are villages where there are community forest farmers who are members of PPHR Lawu Lestari. Felled trees are Tectona, Paraserianthes, Mahagony, and Melia cut all parts of the plant, including its roots. Furthermore, take 10 (ten) sampling in each village. Then dry it and weighing wet or dry weight and calculate for its biomass. The flow of research implementation as in figure 1.
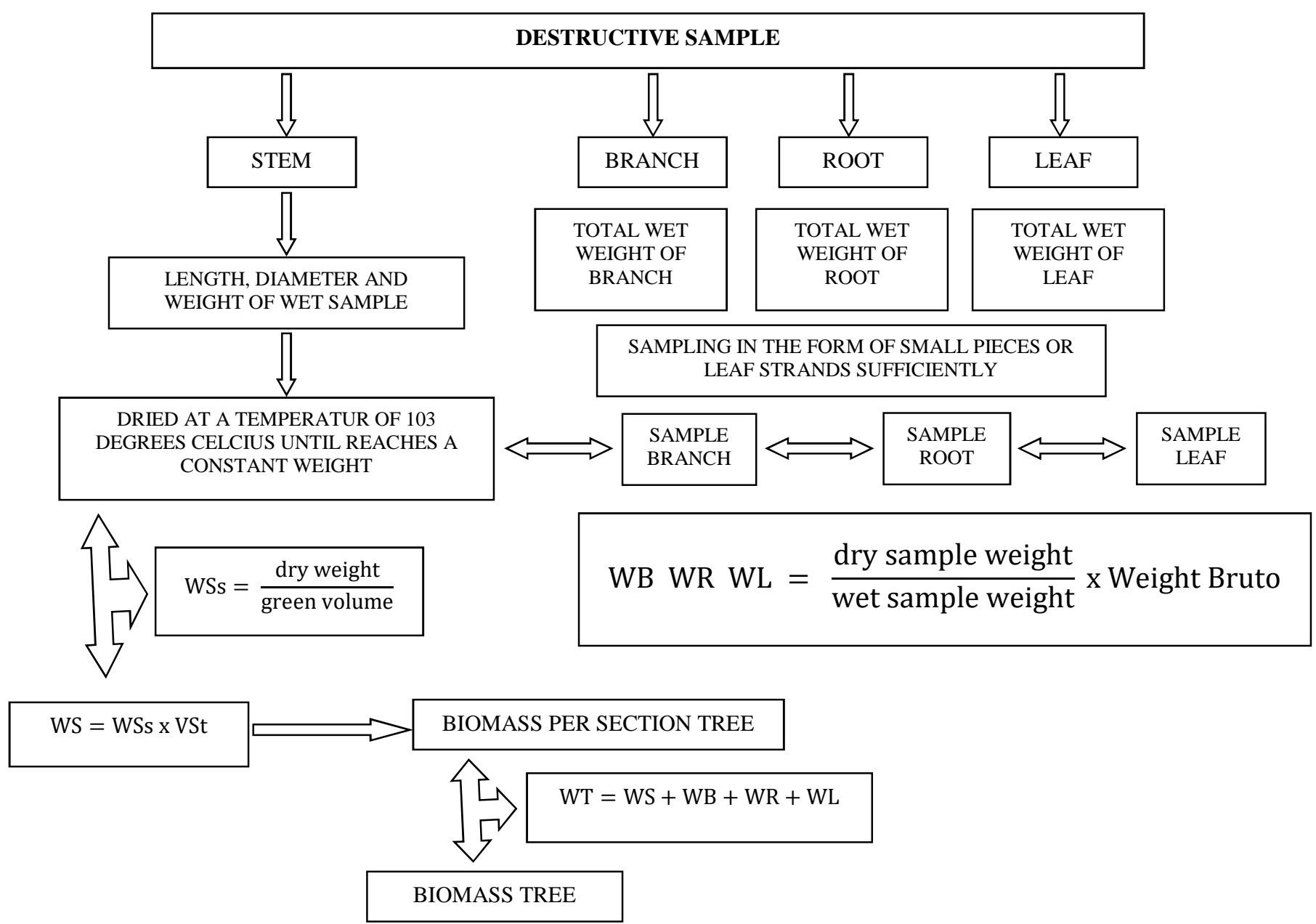

Fig 1. Flow diagram of the calculation of the biomass

The carbon mass is considered to be equal to $50 \%$ biomass or its conversion factor $=0.5$ in estimating the carbon mass potential of a stand regardless of the type of biomass and stand age [15]. The data of carbon content obtained that would be made in an allometric equation with the regression model. The modeling of regression aims to 
estimate or estimate the magnitude of the quantitative effect of one parameter to another. In general, the regression model has the form of the regression equation, and its transformation is presenting in table 1 as follows [16], [17].

TABLE I

REGRESSION EQUATIONS AND ITS TRANSFORMATION

\begin{tabular}{|l|l|l|}
\hline Form Mode & Equation & Linear shape \\
\hline Linear & $\mathrm{Y}=\mathrm{a}+\mathrm{bX}$ & $\mathrm{Y}=\mathrm{a}+\mathrm{bX}$ \\
\hline Qudratic & $\mathrm{Y}=\mathrm{a}+\mathrm{bX}+\mathrm{cX}^{2}$ & $\mathrm{Y}=\mathrm{a}+\mathrm{bX}+\mathrm{cX}^{2}$ \\
\hline Cubic & $\mathrm{Y}=\mathrm{a}+\mathrm{bX}+\mathrm{cX}^{2}+\mathrm{dX}^{3}$ & $\mathrm{Y}=\mathrm{a}+\mathrm{bX}+\mathrm{cX}^{2}+\mathrm{dX}^{3}$ \\
\hline Logarithm & $\mathrm{Y}=\mathrm{a}+\mathrm{b} \ln \mathrm{X}$ & $\mathrm{Y}=\mathrm{a}+\mathrm{b} \ln \mathrm{X}$ \\
\hline Inverse & $\mathrm{Y}=\mathrm{a}+\mathrm{b} / \mathrm{X}$ & $\mathrm{Y}=\mathrm{a}+\mathrm{b} / \mathrm{X}$ \\
\hline Compound & $\mathrm{Y}=\mathrm{ab}^{\mathrm{x}}$ & $\ln \mathrm{Y}=\ln \mathrm{a}+\mathrm{X} \ln \mathrm{b}$ \\
\hline Power & $\mathrm{Y}=\mathrm{a}^{\mathrm{b}}$ & $\ln \mathrm{Y}=\ln \mathrm{a} \mathrm{b} \ln \mathrm{X}$ \\
\hline Sigmoid & $\mathrm{Y}=\mathrm{e}^{\mathrm{a}+\mathrm{b} / \mathrm{t}}$ & $\ln \mathrm{Y}=\mathrm{a}+\mathrm{b} / \mathrm{t}$ \\
\hline Growth & $\mathrm{Y}=\mathrm{e}^{\mathrm{a}+\mathrm{bx}}$ & $\ln \mathrm{Y}=\mathrm{a}+\mathrm{bx}$ \\
\hline Exponential & $\mathrm{Y}=\mathrm{a}\left(\mathrm{e}^{\mathrm{bx}}\right)$ & $\ln \mathrm{Y}=\ln \mathrm{a}+\mathrm{bx}$ \\
\hline Logistic & $\mathrm{Y}=\left(1 / \mathrm{u}+\mathrm{ab}^{2}\right)^{-1}$ & $\ln (1 / \mathrm{Y}-1 / \mathrm{u})=\ln \mathrm{a}+\ln \mathrm{b}$ \\
\hline
\end{tabular}

Selection of the regression model based on the coefficient of determination (R2), the highest as well as the sum of squared error (residual sum of square) the smallest. Beside also tested using a regression model analysis of variance (ANOVA) to determine the level of significance of each of the resulting equations. Processing data using SPSS Statistics 17 [18]. Inventory of the main tree for the community forest done by determining the Sample Plot in 3 village locations (Zone), namely: Ngiliran zone, Bedagung zone, and Jabung zone. In each region, established PM (plot measuring) or recording unit as much as 16 pieces of $25 \times 25$ $\mathrm{m}$ size, so the area of each zone is 1 hectare.

Steps for taking data on each Sample Plot follow the NFI (national forest inventory) standard in document 3 of 2004, as follows [15]:

- Determine the position of latitude and azimuth peg angle plot Example with GPS.

- Determine the angle of direction with the compass to make a plot of measuring (recording unit) as much as 16 plots. Each PM (plot measuring) is the border with a raffia rope.

- Determine the position of latitude and azimuth of central PM point (on tree or tree nearest to center point).

- Inventory number of trees, dbh, tree species, and distribution of tree vegetation on each PM (measured direction and distance to center point) and recorded on the tally sheet. The trees marked are the principal trees of the people's forest composers Mahogany, Melia, Tectona, and Paraserianthes, which have a diameter at breast height $(d b h)$ of at least $5 \mathrm{~cm}$.

Plan Plot Measurement and Recording Unit can be seen in Figure 2.

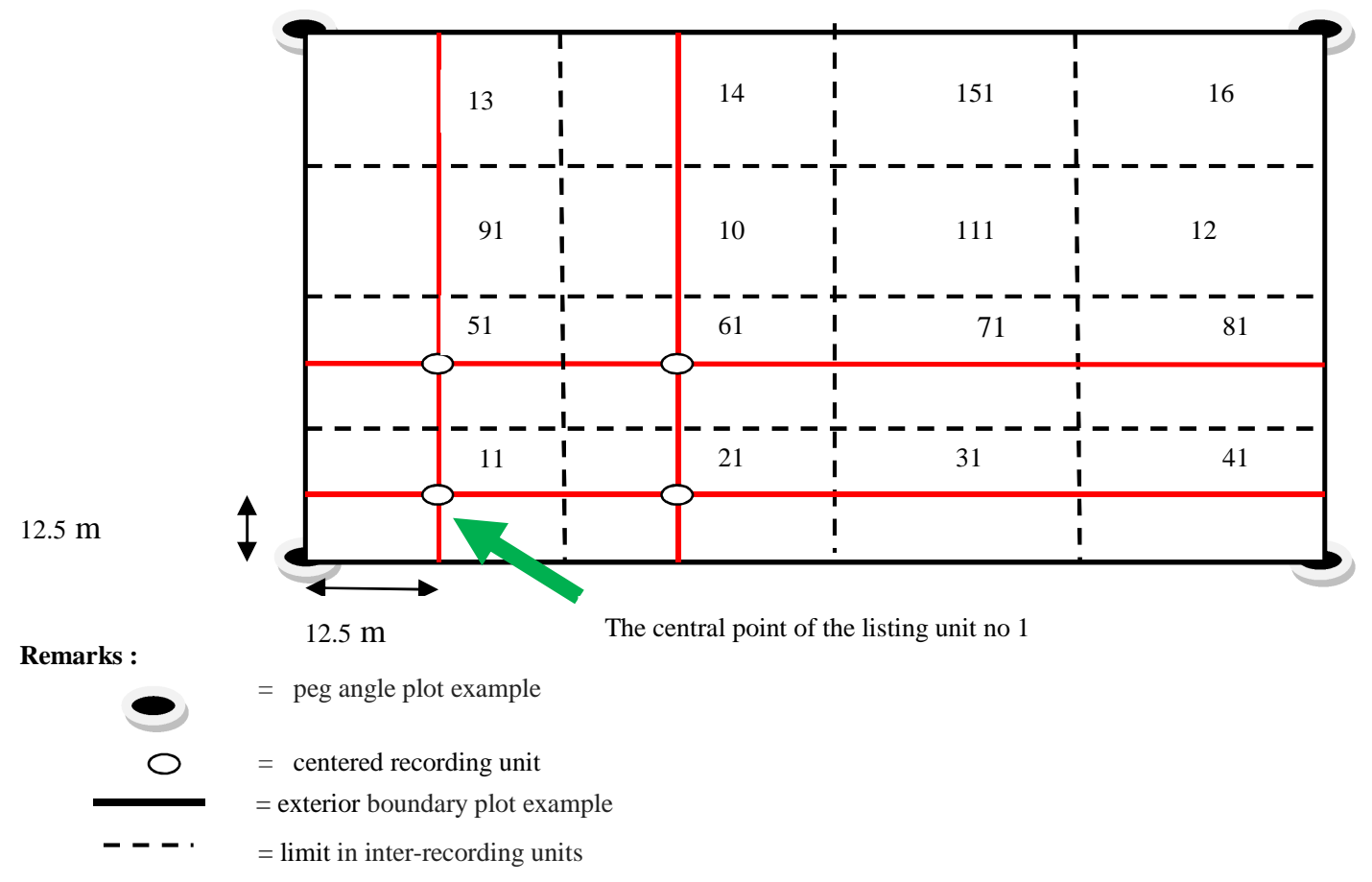

Fig. 2. A plot of Sample plot measuring (recording Unit)

The location of plots in the three village locations which have elevation above sea level between 534 - 670 masl and South Latitude 7036,414 'to 70 36,920`East Longitude 111 016,362 'to 111016,901 '.

\section{RESULTS AND DISCUSSION}

\section{A. Profile of PPHR Lawu Lestari}

Based on the awareness and mutual needs of the members to manage the community's forests sustainably, it formed by Paguyuban Pengelolaan Hutan Rakyat Lawu Lestari in the future abbreviated as PPHR Lawu Lestari. Established on Saturday, 22 June 2013, with legal status notary number 43 and secretariat in Ngiliran Village, Sub District Panekan, District Magetan. While the work area and the number of members as shown in table 2 . 
TABLE II

Distribution OF Work AREAS PPHR LAWU LESTARI AND THE NuMBER OF MEMBERS

\begin{tabular}{|l|c|c|}
\hline \multicolumn{1}{|c|}{ Village } & Sum Members & Area (Ha) \\
\hline Ngiliran & 270 & 137.63 \\
\hline Jabung & 83 & 15.76 \\
\hline Bedagung & 165 & 38.77 \\
\hline T o t a 1 & 518 & 192.16 \\
\hline
\end{tabular}

The oval-shaped seal indicates the identification of the institution with a diameter size of $4 \mathrm{~cm}$ with information about the location of the organization. The vision is "Creating awareness in the business community forest conservation to the welfare and caring for the environment and natural disaster management." The mission is as follows:
- Disseminate people's forest conservation efforts to the entire community.

- Increase capacity, awareness, knowledge, and skills of the community on forest management.

- Maintaining and developing a community forest area with dry land and yard target

- Create productivity business sector forest-based communities.

- Found cooperative PPHR Lawu Lestari.

On December 4, 2013, the PPHR got Timber Legality Certificate issued by PT SGS Indonesia (see www.sgs.com).

\section{B. Calculation Biomass}

The calculation result of average biomass per tree type per part of the tree as in table 3 .

TABLE III

Average Biomass Calculation Results Per Tree Type Per Tree Section

\begin{tabular}{|c|c|c|c|c|c|c|c|c|c|c|c|}
\hline \multirow{3}{*}{ No } & \multirow{3}{*}{ Trees } & \multicolumn{10}{|c|}{ Biomass Part } \\
\hline & & \multicolumn{2}{|c|}{ Leaf } & \multicolumn{2}{|c|}{ Branch and Twigs } & \multicolumn{2}{|c|}{ Root } & \multicolumn{2}{|c|}{ Stem } & \multicolumn{2}{|c|}{ Total } \\
\hline & & Gram & $\%$ & Gram & $\%$ & Gram & $\%$ & Gram & $\%$ & Gram & $\%$ \\
\hline 1. & Mahagony & 30335.9 & 10.70 & 62401.9 & 22.02 & 37439.1 & 13.21 & 153235.5 & 54.07 & 283412.4 & 100,00 \\
\hline 2. & Melia & 25747.0 & 6.93 & 121729.0 & 32.75 & 43856.2 & 11.80 & 180388.1 & 48.53 & 371720.3 & 100,00 \\
\hline 3. & Tectona & 7181.9 & 3.35 & 65812.5 & 30.73 & 39349.2 & 18.37 & 101812.0 & 47.54 & 214155.6 & 100,00 \\
\hline 4. & Paraserianthes & 6854.2 & 9.58 & 13471.1 & 19.21 & 13471.1 & 18.84 & 37454.5 & 52.37 & 71515.9 & 100,00 \\
\hline \multicolumn{2}{|c|}{ Tot a 1} & 70119,0 & 7.46 & 263414.5 & 28.00 & 134115.6 & 14.26 & 472890.1 & 50.28 & 940539.2 & 100.00 \\
\hline \multicolumn{2}{|c|}{ Average } & 17529,8 & 7.46 & 62853.6 & 28.00 & 33528.9 & 14.26 & 118222.5 & 50.28 & 235134.8 & 100.00 \\
\hline
\end{tabular}

While the percentage distribution of biomass per part tree as in the figure 3 .

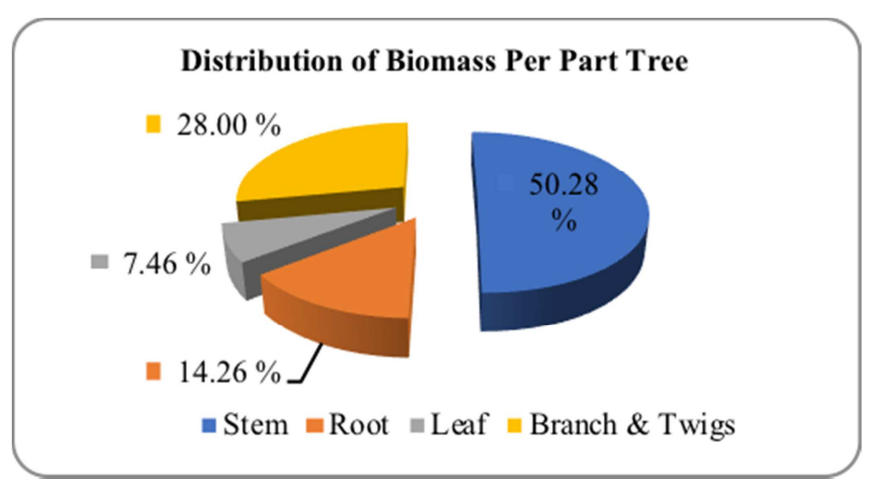

Fig 3. Distribution of Biomass per Part Tree

Based on figure 3 above, it seems that the stem part is the part that has the highest percentage of biomass $(50,28 \%)$; this is by research from hat the main tree trunk has more wood compiler [4] t. Elevated levels of carbon in the stem caused carbon is a dominant element in timber. Wood is composed of lignin, cellulose, hemicellulose, and extractive substances that are mainly composed of carbon parts. Branch sequence $(28,00 \%)$, root $(14,26 \%)$ and last leaf $(7,46 \%)$ low carbon level on leaf caused many parenchyma networks with a thin wall, and the system wall is not only Consists of cellulose alone, but also the pectin and lignin materials are virtually absent.

Moreover, photosynthesis products in the leaves immediately translocated to all parts of the tree to undergo further metabolic processes. While at the root, also there is xylem (wood) network, there are also many phloem and parenchyma networks. Both the phloem and parenchymal networks have thin walls and almost non-existent lignin [17].

\section{Estimation of Carbon Content}

The biomass calculation results from each tree type are continuing by estimating how much carbon content is. Carbon mass is considered to be equal to $50 \%$ biomass or its conversion factor $=0.5$ in estimating the carbon mass potential of a stand regardless of the type of biomass and stand age [16], [19]. The result of the carbon estimation was made by allometric model equations using SPSS statistics 17 . The exact equation model was chosen based on the most considerable R2 value, the least square, and the significant number of squares error based on the analysis of variance (ANOVA). The most appropriate model for the tree of the community forest in table 4 below:

TABLE IV

Model of Allometric EQuATions of MAIN TYPe OF PEOPLE Forest CONSTRUCTOR

\begin{tabular}{|l|l|l|l|c|c|}
\hline No & Trees & $\begin{array}{l}\text { Equation } \\
\text { Model }\end{array}$ & $\begin{array}{c}\text { Model } \\
\text { Form }\end{array}$ & $\mathrm{R}^{2}$ & SEE \\
\hline 1 & Melia & $\begin{array}{l}\mathrm{Y}=246.12 \mathrm{~d} \\
1.986\end{array}$ & Power & 0.999 & 0.053 \\
\hline 2 & Mahagony & $\begin{array}{l}\mathrm{Y}=48.389 \mathrm{~d} \\
2.443\end{array}$ & Power & 0.997 & 0.083 \\
\hline 3 & Tectona & $\begin{array}{l}\mathrm{Y}=65.019 \mathrm{~d} \\
2.370\end{array}$ & Power & 0.989 & 0.122 \\
\hline 4 & Paraserianthes & $\begin{array}{l}\mathrm{Y}=52.726 \mathrm{~d} \\
2.116\end{array}$ & Power & 0.993 & 0.128 \\
\hline
\end{tabular}

Table 4 shows that for the type of teak. The allometric equation $\mathrm{Y}=65,019 \mathrm{~d} 2,370$, this result is more 
corresponding when compared with the outcome of research done with model equation $\mathrm{Y}=33 \mathrm{~d} 2,635$ [19]. Because the carbon content is calculated only on the amount of carbon above ground alone for the root part is not included.

In table 4 for mahogany allometric equation $\mathrm{Y}=48,389 \mathrm{~d}$ 2,443 where this result is by research [20] with value $\mathrm{Y}=44$ $\mathrm{d} 2,541$. The relationship between the carbon content and the diameter at breast height $(d b h)$ of Melia tree with the model of equation $\mathrm{Y}=246,123 \mathrm{~d}$ 1,986 presented in figure 4 .

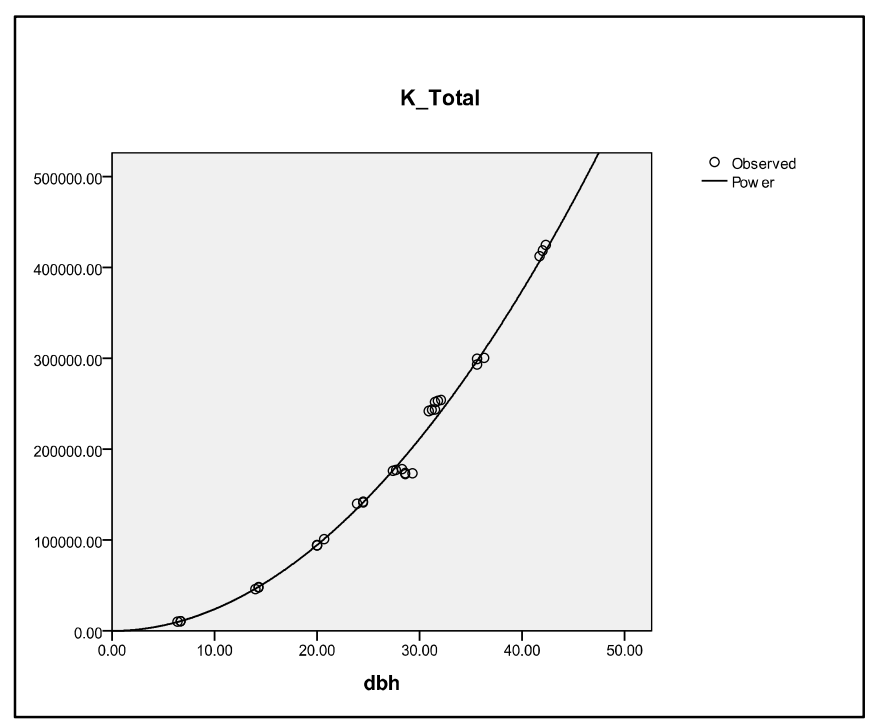

Fig 4. Relationship diameter at breast height $(d b h)$ with Melia tree carbon content with allometric equation model $\mathrm{Y}=246,123 \mathrm{~d}^{1,986}$

From Figure 4, it can say that the value of an in the Melia allometric equation type is the best compared to the other three types, this is because this type is hardwood and has a high density. In a study conducted by, the allometric equation used for Melia was $\mathrm{W}=110 \mathrm{~d}^{2.62}$ [19]. Variations were also influenced by forest type, vegetation type, climate type and rainfall, topography, and other biophysical conditions, including silvicultural techniques and applied forest management [21].

The relationship between diameter at breast height $(d b h)$ and carbon content of Mahogany tree with model equation $\mathrm{Y}=48,389 \mathrm{~d}^{2,443}$ presented in figure 5 .

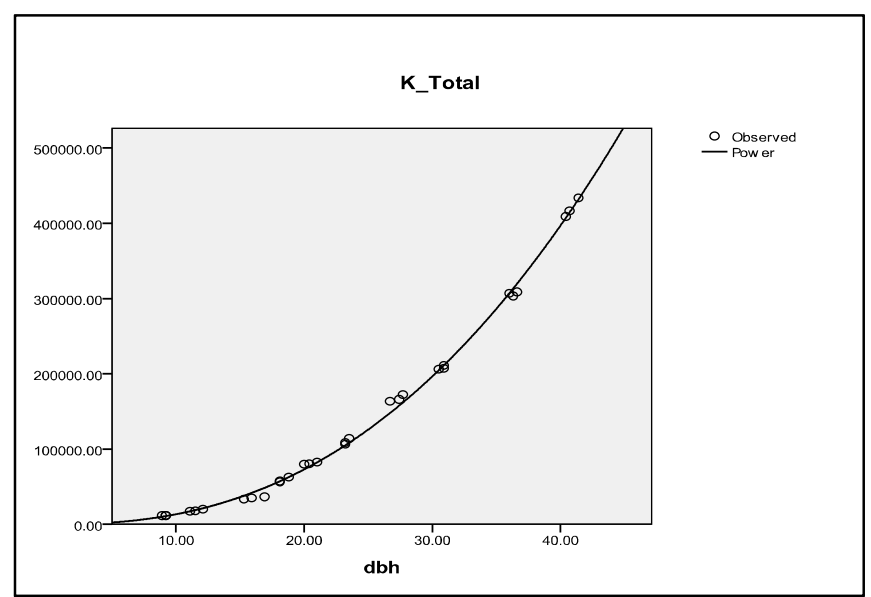

Fig 5. Relationship diameter at breast height $(d b h)$ with Mahagony tree carbon content with allometric equation model $\mathrm{Y}=48,389 \mathrm{~d}^{2,443}$
From Figure 5, it can say that the value of an in the Mahogany allometric equation is the smallest compared to the other three types, this is because this type includes softwood in small diameter but grew harder as the diameter increases, which causes the value of $b$ to become significant. The allometric equation used for mahogany is $\mathrm{Y}=48 \mathrm{~d}^{0.68}$ [22]. This difference in value is due to measurements only made for carbon above ground level.

The relationship between diameter at breast height $(d b h)$ and carbon content of Tectona tree with model equation $\mathrm{Y}=$ $65,019 \mathrm{~d}^{2,370}$ presented in figure 6 .

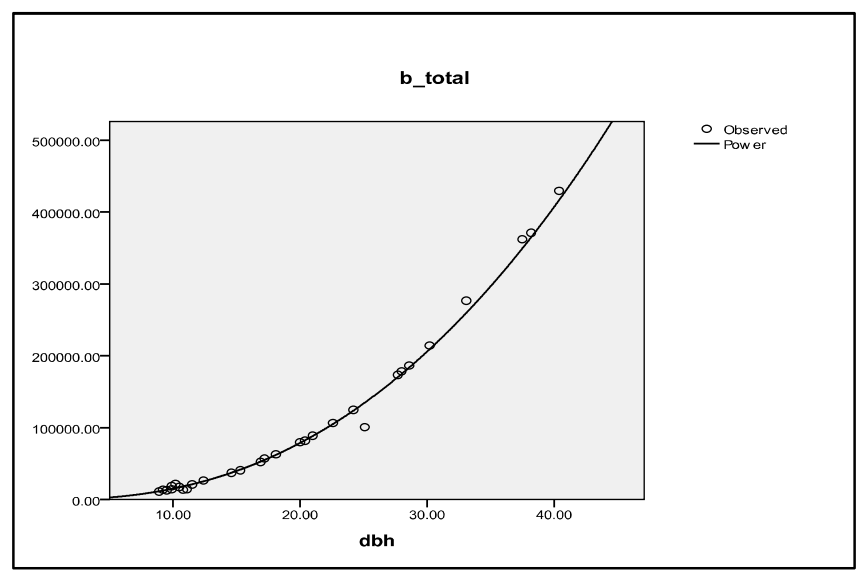

Fig 6. Relationship diameter at breast height $(d b h)$ with Tectona tree carbon content with allometric equation model $\mathrm{Y}=65,019 \mathrm{~d}^{2,370}$

From Figure 6, it can say that the value of an in the allometric equation of the Tectona type has a second considerable value after Melia, this is because this type includes hardwoods of small diameter but will grow harder as the diameter increases causing the value of $b$ to become significant. The allometric equation used for Tectona was $\mathrm{Y}$ $=43.9 \mathrm{~d} 2.759$ [23]. This lower number difference was due to the type of Tectona requiring nutrition and space for growth and starting to grow poorly in the area, which has a height above 800 masl Whereas in this study carried out at locations that have an altitude of 534 - 670 masl.

The relationship between diameter at breast height $(d b h)$ and carbon content of Paraserianthes tree with model equation $\mathrm{Y}=52,726 \mathrm{~d} 2,116$ can be presented in figure 7 .

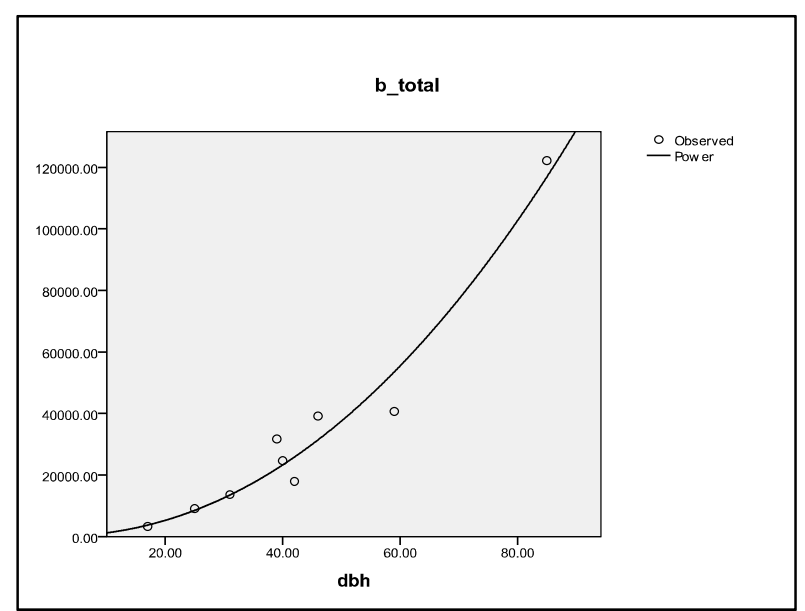

Fig 7. Relationship diameter at breast height $(d b h)$ with Paraserianthes tree carbon content with allometric equation model $\mathrm{Y}=52,726 \mathrm{~d}^{2,116}$ 
From Figure 7, it can say that the value of an in the allometric equation of the Paraserianthes type has a second small value before Swietenia, this is due to this type including softwood in small diameter but will grow harder as the diameter increases which causes the value of $b$ to be significant but still lower than Swietenia. The allometric equation used for Paraserianthes was $\mathrm{Y}=27.2 \mathrm{~d} 2,831$ [24]. This lower difference in numbers was due to the type of Paraserianthes planted in agroforestry with annual crops, while in the study site, most planted pure.

\section{Inventory Results}

The calculation result of the carbon number of the primary tree of people forest per zone/research village by type can see in table 5 .

TABLE V

Number of CARbon CONTENT PER TREes PER VILlage

\begin{tabular}{|l|r|r|r|r|r|}
\hline \multirow{2}{*}{ Trees } & \multicolumn{2}{|c|}{$\begin{array}{c}\text { Number of Carbon per species } \\
\text { (tonnes) from 3 villages }\end{array}$} & \multicolumn{2}{|c|}{ Total (Tones) } \\
\cline { 2 - 4 } & Ngiliran & Jabung & Bedagung & \multicolumn{2}{|c|}{} \\
\cline { 2 - 4 } & & & & Carbon & Percent \\
\hline Melia & 2.358 & 1.325 & 2.919 & 6.602 & 15.33 \\
\hline Mahagony & 2.587 & 3.845 & 2.138 & 8.570 & 19.86 \\
\hline Tectona & 0.416 & 0.510 & 0.572 & 1.498 & 3.48 \\
\hline Paraserianthes & 7.416 & 10.630 & 8.380 & 26.426 & 61.33 \\
\hline Total & 12.777 & 16.310 & 14.009 & 43.096 & 100.00 \\
\hline
\end{tabular}

Table 5 shows that the most abundant carbon content in Jabung Village is 16,310 tons/ha. This is due to smallholder forest farmers in Jabung Village. Most grown by pure stands rather than agroforestry, and most planted with Paraserianthes, Mahogany, Melia, and Tectona.

Dominant species in the community forest in the study sites were Paraserianthes type with 61.33 percentage, and the Tectona type was the lowest with 3.48. Because in that area, the kind of Paraserianthes is the type favored by local people besides wood, also growth and leaves that can quickly utilize for animal feed. In contrast, the Tectona type requires nutrients and space for growth and begins to grow poorly in areas that have altitudes above 500 masl. The mean carbon content per hectare presented in table 6 .

TABLE VI

Calculation OF CARBon CONTENT PER Hectare

\begin{tabular}{|l|c|r|r|}
\hline Village & $\begin{array}{c}\text { Carbon Content } \\
\text { (tonnes) }\end{array}$ & $\begin{array}{c}\text { Wide Forest } \\
\text { Area (Ha) }\end{array}$ & CC x WFA \\
\hline Ngiliran & 12.777 & 137.63 & 1758.50 \\
\hline Jabung & 16.310 & 15.76 & 257.06 \\
\hline Bedagung & 14.009 & 38.77 & 543.13 \\
\hline T o t a 1 & 41.096 & 192.16 & 2558.69 \\
\hline
\end{tabular}

Based on table 6 above, the mean carbon content per hectare at the study site was $2558,69 / 192,16=13.32$ ton/ha, while the carbon content of community forest in the study site was 2558.69 tons. This result is better thana [25] where the average stand is $7.61 \mathrm{ton} / \mathrm{ha}$; This is because community forest consists of various species and most large-diameter trees, while the Melaleuca tree is short and often harvested. The average carbon stock of community forests reached 72.73 tons/ha [26], while the average carbon reserves of community forests reached 99.92 tons/ha [27]. The difference in the amount of carbon content is because in this study measured only the contents of 4 main types of trees making up community forest, not the whole of the community forest ecosystem.

\section{CONCLUSION}

The average biomass per part of the tree ranging from the most substantial portion is the stem with a percentage of $50.28 \%$, followed by branches up to $28.00 \%$, then roots $14.26 \%$ and the smallest leaves of $7.46 \%$. The equation model for estimating Mindi tree carbon content is $\mathrm{Y}=246,123 \mathrm{~d}^{1,986}$, Mahogany $\mathrm{Y}=48,389 \mathrm{~d}^{2,443}$, Tectona $\mathrm{Y}=65,019 \mathrm{~d}^{2,370}$ and Paraserianthes $\mathrm{Y}=52,726 \mathrm{~d}^{2,116}$. The amount of carbon content in PPHR Lawu Lestari is 2558.69 tons.

\section{ACKNOWLEDGMENT}

We are grateful to some parties for the research fundings; they are as follows: (1) Minister of Research and the Higher Education Republic of Indonesia through DRPM grant scheme year 2016 and 2017 Grant Applied Product. (2) The Head of LLDIKTI VII Surabaya, (3) The Rector of Universitas Merdeka Madiun, (4) The Chairman of the Institute for Research and Community Services of Universitas Merdeka Madiun.

\section{REFERENCES}

[1] T. A. Ontl et al., "Forest Management for Carbon Sequestration and Climate Adaptation," J. For., vol. 118, no. 1, pp. 86-101, Nov. 2019.

[2] D. Lin and Y. Lin, "Stakeholders of Voluntary Forest Carbon Offset Projects in China: An Empirical Analysis," Adv. Meteorol., vol. 2015, p. $518698,2015$.

[3] E. Yosefi Suryandari, D. Djaenudin, S. Astana, and I. Alviya, "Dampak Implementasi Sertifikasi Verifikasi Legalitas Kayu Terhadap Keberlanjutan Industri Kayu dan Hutan Rakyat," J. Penelit. Sos. dan Ekon. Kehutan., vol. 14, no. 1, pp. 19-37, Apr. 2017.

[4] R. Setiahadi, "How Significant is the Existence of Forest Community Contribution in GHG Emissions Reduction?," J. Eng. Appl. Sci., pp. 4826-4830, 2017.

[5] Z. Chen, G. Yu, and Q. Wang, "Effects of climate and forest age on the ecosystem carbon exchange of afforestation," J. For. Res., vol. 31, no. 2, pp. 365-374, 2020.

[6] S. Ma et al., "Variations and determinants of carbon content in plants: a global synthesis," Biogeosciences, vol. 15, no. 3, pp. 693-702, Feb. 2018 .

[7] D. Bert and F. Danjon, "Carbon concentration variations in the roots, stem and crown of mature Pinus pinaster (Ait.)," For. Ecol. Manage., vol. 222, no. 1-3, pp. 279-295, Feb. 2006

[8] V. B. Arifanti, I. W. S. Dharmawan, and D. Wicaksono, "Carbon Stock Potency of Sub Montane Forest Stand in Mount Halimun Salak National Park," For. Socio Econ. Res. J., vol. 11, no. 493, pp. 13-31, 2014.

[9] G. D. Wright, K. P. Andersson, C. C. Gibson, and T. P. Evans, "Decentralization can help reduce deforestation when user groups engage with local government," Proc. Natl. Acad. Sci., vol. 113, no. 52, pp. 14958-14963, Dec. 2016.

[10] E. Union, "Indonesia VPA Annual Report 2016," 2016.

[11] E. Union, "Summary of Indonesia-European Union Action Plan on the Advancement of VPA Implementation_2015," 2015.

[12] E. Yosefi Suryandari, D. Djaenudin, and I. Alviya, "Persepsi Pelaku Hutan Rakyat dan Industri Kayu Skala Kecil-Menengah Terhadap Kesiapan Implementasi SVLK," J. Anal. Kebijak. Kehutan., vol. 14, no. 2, pp. 149-164, Nov. 2017.

[13] A. Sudrajat, Hardjanto, and L. Sundawati, "Farmer Participation on Sustainable Private Forest Management: Case of Cikeusal and Kananga Villages, Kuningan District Partisipasi Petani Dalam Pengelolaan Hutan Rakyat Lestari," J. Silvikultur Trop., vol. 7, no. 1, pp. 8-17, 2016. 
[14] Q. M. Ketterings, R. Coe, M. van Noordwijk, Y. Ambagau', and C. A. Palm, "Reducing uncertainty in the use of allometric biomass equations for predicting above-ground tree biomass in mixed secondary forests," For. Ecol. Manage., vol. 146, no. 1-3, pp. 199209, Jun. 2001.

[15] K. Hairiah, S. Rahayu, and Berlian, "Layanan lingkungan agroforestri berbasis kopi: Cadangan karbon dalam biomasa pohon dan bahan organik tanah (studi kasus dari Sumberjaya, Lampung Barat)," Agrivita, vol. 28, no. 3, pp. 298-309, 2006.

[16] I. Sharma and S. Kakchapati, "Linear Regression Model to Identify the Factors Associated with Carbon Stock in Chure Forest of Nepal," Scientifica (Cairo)., vol. 2018, p. 1383482, 2018.

[17] D. Maniatis et al., "Evaluating the Potential of Commercial Forest Inventory Data to Report on Forest Carbon Stock and Forest Carbon Stock Changes for REDD+ under the UNFCCC," Int. J. For. Res., vol. 2011, p. 134526, 2011.

[18] M. Iqbal, "Pengolahan Data dengan Regresi Linier Berganda," Perbanas Inst. Jakarta, vol. 4, pp. 1985-2000, 2000.

[19] I. Samsoedin, I. W. S. Dharmawan, and C. A. Siregar, "Carbon Biomass Potency of Old Growth Forest and Thirty Year-Old Logged Over Forest in Malinau Research Forest, East Kalimantan," J. Penelit. Hutan dan Konserv. Alam, vol. 6, no. 1, pp. 47-56, 2009.

[20] M. Lokbere, H. N. Pollo, and J. S. Tasirin, "Estimasi Biomassa Pohon Mahoni (Swietenia Macrophylla King) di Areal UNSRAT," vol. 23, no. 6, pp. 2-8, 2017.
[21] Chairul, E. Muchktar, Mansyurdin, T. M, and G. Indra, "The Structure of Vegetation Density and The Estimation of Carbon Content in Some Conditions of Forest in Siberut Island, West Sumatera," J. Biol. Sci., vol. III, no. 1, pp. 15-22, Oct. 2016.

[22] G. Kafle, "Vertical Distribution of Soil Organic Carbon and Nitrogen in a Tropical Community Forest of Nepal," Int. J. For. Res., vol. 2019, p. 3087570, 2019.

[23] Marjan, Wardah, and A. Hapid, "Biomassa dan Karbon Pohon di Sekitar Danau Tambing pada Kawasan Taman Nasional Lore Lindu Desa Sedoa Kecamatan Lore Utara Kabupaten Poso," War. Rimba, vol. 4, pp. 82-88, 2016.

[24] K. Meilani and N. Wijayanto, "Potential carbon storage in agroforestry-based community forest in Sellawi, Garut, West Java," 2018, vol. 5, no. 5, pp. 113-148.

[25] M. Lukito and R. Purwanto, "Inventarisasi hutan tanaman kayu putih ( Mellaleuca cajuputi subsp cajuputi powell ) dalam menghasilkan biomassa dan karbon hutan:: Kasus di hutan tanaman kayu putih BKPH Sukun , KPH Madiun Perum erhutani Unit II Jawa Timur," Gadjah Mada University, 2010.

[26] D. Ivando, I. S. Banuwa, and A. Bintoro, "Karbon Tersimpan pada Berbagai Tipe Kerapatan Tegakan di Hutan Rakyat," J. Belantara, vol. 2, no. 1, pp. 53-61, Mar. 2019.

[27] L. Ristiara, R. Hilmanto, and D. Duryat, "Estimasi Karbon Tersimpan Pada Hutan Rakyat Di Pekon Kelungu Kabupaten Tanggamus,” J. Sylva Lestari, vol. 5, no. 1, p. 128, Jan. 2017. 